\title{
Performance of dairy calves fed milk, milk replacer or post-weaning concentrate with acidifiers ${ }^{1}$
}

\section{Marinaldo Divino Ribeiro ${ }^{2 *}$, José Carlos Pereira ${ }^{3}$, Augusto César de Queiroz ${ }^{3}$, Paulo Roberto Cecon ${ }^{4}$, Edenio Detmann ${ }^{3}$, José Augusto Gomes Azevêdo ${ }^{2}$}

1 Trabalho financiado pelo CNPq

2 Programa de Pós-Graduação em Zootecnia - UFV.

${ }^{3}$ Departamento de Zootecnia - UFV. Pesquisador do CNPq.

${ }^{4}$ Departamento de Informática - UFV.

\begin{abstract}
The objective of this study was to evaluate the effect of the addition of acidifiers to milk, milk replacer or post-weaning concentrate on the performance and health status of weaning and post-weaning calves. Three experiments were carried out, in the first experiment 62 Holstein $\times$ Zebu crossbred calves (males and females), reared from birth to 60 days of age, were distributed and fed milk with or without acidifier. From the third day, the calves were suckled (5L of milk/d) for 56 days, split into two meals. The acidifier was added to milk at the time of feeding. From the second week of calf's age a starter diet (18\% of CP) was also offer. In second experiment, the same animals from first experiment, but from 61 to 120 days of age were distributed and fed $(2 \mathrm{~kg} / \mathrm{d})$ post-weaning concentrate $(18 \%$ of CP) with or without acidifier and Cynodon dactylon hay ad libitum. In third experiment, 16 male Holstein $\times$ Zebu crossbred calves, reared from birth to 60 days of age, were distributed and fed milk replacer with or without acidifier. The acidifier used in the first and third experiments was composed by the citric, lactic, fumaric, and phosphoric acids, and vitamin C (liquid diet); and by betaglucans, flavonoides, linoleic and oleic and citric acids, and vitamin C (solid diet). The addition of acidifier to milk or to post-weaning concentrate did not affect the dry matter (DM) and CP intakes, which were 818 and 196; 1740 and 217 g/d respectively. Similarly, it did not show high average daily gains, with 525 and 513 g/d, respectively. The addition of acidifiers to milk replacer showed results similar to those observed in calves fed milk. Therefore, the use of acidifiers in milk, milk replacer or in the post-weaning concentrate did not result in beneficial effects for calves.
\end{abstract}

Key Words: additive, average daily gain, nursing phase

\section{Desempenho de bezerros leiteiros alimentados com leite, sucedâneo do leite ou concentrado pós-desmame com acidificantes}

\footnotetext{
RESUMO - Objetivou-se avaliar o efeito da adição de acidificantes ao leite, sucedâneo do leite ou concentrado pósdesmame sobre o desempenho e o status de saúde de bezerros ao desmame e pós-desmame. Três experimentos foram realizados: no primeiro experimento, 62 bezerros mestiço Holandês $\times$ Zebu (machos e fêmeas), criados a partir do nascimento ate 60 dias de idade, foram distribuídos e alimentados com leite com ou sem acidificante. A partir do terceiro dia, os bezerros foram aleitados (5 L de leite/dia) por 56 dias, divididos em duas refeições. O acidificante foi adicionado ao leite no momento da alimentação. A partir da segunda semana de idade do bezerro, uma dieta inicial (18\% de proteína bruta,PB) foi também oferecida. No segundo experimento, os mesmos animais do primeiro experimento, mas dos 61 aos 120 dias de idade, foram distribuídos e alimentados ( $2 \mathrm{~kg} /$ dia) com concentrado pós-desmame (18\% de PB) com ou sem acidificante e feno Cynodon dactylon à vontade. No terceiro experimento, 16 bezerros machos, mestiço Holandês $\times$ Zebu, criados do nascimento até aos 60 dias de idade, foram distribuídos e alimentados com substitutos do leite, com ou sem acidificante. O acidificante utilizado no primeiro e terceiro experimentos foi composto pelos ácidos cítrico, lático, fumárico, fosfórico e vitamina $C$ (dieta líquida) e por betaglucanas, flavonoides, ácidos linoléico, oleico e cítrico e vitamina C (dieta sólida). A adição de acidificante ao leite ou ao concentrado pós-desmame não afetou a ingestão de matéria seca (MS) e de PB, que foram 818 e 196, 1740 e 217 g/dia, respectivamente. Do mesmo modo, não apresentaram grande ganhos médios diários com 525 e 513 g/dia, respectivamente. A adição de acidificante ao sucedâneo do leite apresentou resultados semelhantes aos observados nos bezerros alimentados com leite. Portanto, o uso de acidificantes no leite, sucedâneo do leite ou no concentrado pósdesmame não tem efeitos benéficos em bezerros.
}

Palavras-chave: aditivo, aleitamento, ganho de peso 


\section{Introduction}

The four months of life of the calves is characterized by a large exposure to different environment, handling and feeding conditions, as well as changes in the digestive physiology and the ability to use nutrients in the diet. The times of greatest exposure to these conditions are: the initial days after birth, where the calves lose their maternal protection and are exposed to a variety of pathogens, the period for inclusion of solid feed to diet, which characterizes nutritional stress as result of the physiological adaptation for the use of such feed, and the period shortly after weaning, because the animals are submitted to environment and handling changes, fed only solid diet, with higher fiber content.

Typically, these are stress periods that most health problems occur due to lower immune capacity to respond to infectious agents. The main problem observed during stress periods in calves is diarrhea (Quigley et al., 1997 and Marques, 2003), which requires intervention, and may require the use of antimicrobials. In the absence of adequate handling, the morbidity and mortality rates are even higher (Marques, 2003), which result in impairment of animal performance and expensive costs. Thus, the preventive intervention is a recommended strategy. As a preventive measure alternative to the use of antibiotics, acidifiers are recommended (Palenzuela, 2003).

Acidifiers have bacteriostatic and bactericidal action when used in appropriate doses (Salmond et al., 1984; Young \& Foegeding, 1993). Acidification of feed has the potential to control the proliferation and activity of bacteria and could improve animal growth and feed efficiency, because it can eliminate undesirable microorganisms that compete for nutrients. Similar benefits are attributed to antibiotics. However, acidifiers leave no residue in the carcass and do not promote the appearance of resistant bacteria.

The objective of this work was to evaluate the effect of an organic acid compounds (acidifier) added to milk, milk replacer or to post-weaning concentrate on performance and health status of weaning and post-weaning calves.

\section{Material and Methods}

Three experiments were carried out, the first and two have been conducted in the period from November 2003 to April 2004 at EMBRAPA- Gado de Leite- MG, Brasil; and the third experiment was conducted at Universidade Federal de Viçosa - MG-Brasil, in the period from April to June 2004.
In the first experiment, 62 Holstein $\times$ Zebu crossbred calves (males and females) were reared from birth to 60 days of age. In second experiment, the same animals as those from the first experiment were used but from 60 days to 112 days of age, that is, the post-weaning period. In third experiment, 16 Holstein $\times$ Zebu crossbred male calves were reared from birth to 60 days of age, on average. In the three experiments, milk, milk replacer and concentrate (3) with or without acidifier were, respectively, studied.

The acidifier was composed ( $\mathrm{kg}$ of product) by $400 \mathrm{~g}$ of citric acid, $180 \mathrm{~g}$ of lactic acid, $20 \mathrm{~g}$ of fumaric acid, $15 \mathrm{~g}$ of phosphoric acid and $5.2 \mathrm{~g}$ of vitamin $\mathrm{C}$ and was used in first and third experiments (liquid diets). And, in the second experiment (solid diet) was composed (kg of product) by $80 \mathrm{~g}$ of betaglucans, $4 \mathrm{~g}$ of flavonoids, $3 \mathrm{~g}$ of linoleic acid, $1 \mathrm{~g}$ of oleic acid, $55 \mathrm{~g}$ of citric acid and $2.4 \mathrm{~g}$ of vitamin $C$ The composition of the acidifiers was in according to the commercial manufacturer. The commercial mill replacer was used and prepared according to manufacturer guides.

In the weaning phase, the acidifier was mixed to the milk or milk replacer at the level of $0.5 \%$ at the time of feeding. In the post-weaning, it was added to the post-weaning concentrate, at the level of $0.4 \%$.

Calves were kept in individual hutches, and fed colostrum for 3 days prior to the access to milk or milk replacer and was fed for 56 days with $5 \mathrm{~L} / \mathrm{d}$ of milk or milk replacer (Table 1), offered in the morning ( $3 \mathrm{~L}$ ) and evening (2 L) with or without acidifier. From the second week of age on and during the weaning phase, the calves were fed a starter diet (18\% of CP) ad libitum up to $2 \mathrm{~kg} / \mathrm{d}$ (Table 1). The post-weaning concentrate (composed by ground corn, $74 \%$, soybean meal, $22 \%$, mineral salt, $4 \%-18 \%$ of CP) was used with or without acidifier. After weaning, the offer of post-weaning concentrate was limited to $2 \mathrm{~kg} / \mathrm{d}$. Coast-cross hay was offered only in the post-weaning phase (Table 1).

The individual and daily milk, milk replacer, postweaning concentrate and hay intakes were obtained by the difference in weight between the amount offered and orts.

In the first and third experiment calves were weighed at birth, and to 28 and 56 days of age; in the second experiment: at 56, 88 and 112 days of age, with fasting (solids) of approximately 12 to 14 hours.

The occurrence of diarrhea was recorded by daily individual tracking of calves in the morning before feeding. The feces consistency of each calf was recorded, with score 1 for normal feces and 2 for diarrhea. Runny nose occurrence was also daily recorded, with score 1 for animals without runny nose and 2 for those with runny nose. 
Table 1 - Composition of feed supplied to calves (\% DM)

\begin{tabular}{|c|c|c|c|c|c|}
\hline Nutrient (\%) & Milk & Milk replacer & Starter diet & Post-weaning concentrate & Coast-cross hay \\
\hline Organic matter & - & - & 88.00 & 89.58 & 89.24 \\
\hline Ether extract & 3.90 & 1.55 & 5.00 & 0.62 & 1.82 \\
\hline Neutral detergent fiber & - & - & 7.50 & 11.72 & 71.72 \\
\hline Total carbohydrates & - & - & 99.65 & 70.90 & 76.68 \\
\hline Ashes & 0.65 & 0.76 & 12.00 & 10.42 & 10.76 \\
\hline
\end{tabular}

Fecal samples were weekly collected directly from the rectum of the calves, properly identified and then refrigerated to prevent the incubation and eclosion of larvae. Part of the material, in the third experiment, was immediately used for $\mathrm{pH}$ determination. The other part was used in calculating the number of helminthes eggs/g of feces (EPG), using the centrifugal-flotation technique in saturated sugar solution (Sheater, 1923).

Data related to average daily gain, feed intake, feed efficiency and $\mathrm{pH}$ of fecal samples were submitted to analysis of variance for the three periods considered in each experiment: In the first and third experiment: from 0 to 4,5 to 8 and from 0 to $8 \mathrm{wk}$ (weaning) and in the second experiment: from 9 to 12,13 to 16 and from 9 to $16 \mathrm{wk}$ (postweaning), using the Statistical Analysis System software (SAS, 2000). For all the characteristics, body weight and the occurrence of diarrhea were included as covariates in the model analyze. The inclusion of diarrhea to the model as covariate was based on Lima \& Guidoni (1994). The data related to the occurrence of diarrhea and runny nose were interpreted through the use of the chi-square test (Gomes, 1963; Magalhaes \& Lima, 2001).

As the distribution of EPG data showed a non-normal distribution, the logarithmic transformation of data was performed, according to Snedocor \& Cochran (1989), normally applied when the standard deviation is proportional to the mean, for the confirmation of significant differences of the number of EPG determined by the experimental treatments.

\section{Results and Discussion}

In the first experiment, there was no effect $(\mathrm{P}>0.05)$ of milk with or without acidifier to on DM and CP intakes $(\mathrm{kg} / \mathrm{d}$ or \% BW) at different age groups of calves (Table 2).

The mean DM intake (kg/day), regardless the addition of acidifier to milk, during the first four wk was $0.68 \mathrm{~kg} / \mathrm{d}$. This value was basically due to the intake observed over the last two wk of the period, where the calves had an average
Table 2 - Dry matter and crude protein intakes of calves fed milk with or without acidifier at different age groups

\begin{tabular}{|c|c|c|c|c|}
\hline \multirow{2}{*}{$\begin{array}{l}\text { Nutrient } \\
\text { intake }\end{array}$} & \multirow{2}{*}{$\begin{array}{c}\text { Calf age } \\
\text { group (wk) }\end{array}$} & \multicolumn{2}{|c|}{ Milk } & \multirow[t]{2}{*}{ CV (\%) } \\
\hline & & $\begin{array}{c}\text { With } \\
\text { acidifier }\end{array}$ & $\begin{array}{l}\text { Without } \\
\text { acidifier }\end{array}$ & \\
\hline & \multicolumn{4}{|c|}{$\mathrm{kg} / \mathrm{d}$} \\
\hline \multirow[t]{3}{*}{ Dry matter } & 0 to 4 & 0.6855 & 0.6835 & 4.29 \\
\hline & 5 to 8 & 0.9465 & 0.9576 & 17.65 \\
\hline & 0 to 8 & 0.8160 & 0.8205 & 11.05 \\
\hline \multirow[t]{4}{*}{ Crude protein } & 0 to 4 & 0.1718 & 0.1711 & 3.50 \\
\hline & 5 to 8 & 0.2201 & 0.2221 & 13.68 \\
\hline & 0 to 8 & 0.1960 & 0.1966 & 8.35 \\
\hline & \multicolumn{4}{|c|}{$\% \mathrm{BW}$} \\
\hline \multirow[t]{3}{*}{ Dry matter } & 0 to 4 & 1.58 & 1.56 & 10.26 \\
\hline & 5 to 8 & 1.61 & 1.59 & 16.84 \\
\hline & 0 to 8 & 1.39 & 1.36 & 12.54 \\
\hline \multirow[t]{3}{*}{ Crude protein } & 0 to 4 & 0.40 & 0.39 & 9.85 \\
\hline & 5 to 8 & 0.37 & 0.37 & 13.99 \\
\hline & 0 to 8 & 0.33 & 0.33 & 11.35 \\
\hline
\end{tabular}

age from 28 to 30 days. Greenwood et al. (1997) working with three DM intake levels as percent of the birth weight: $1,1.5$ and $2 \%$ and concluded that the intake of $1.5 \%$ was the most appropriate. In this condition, the animals should be consuming $700 \mathrm{~g} / \mathrm{d}$ of DM for three consecutive days. Considering that the intakes were adjusted for the co-variable birth weight and were close to those referenced by the authors, it could be inferred that the calves could already be weaned around 30 days of age. This early weaning procedure was an appropriate strategy to increase the amount of milk available for market and to reduce the costs of creating the animals, without any harm for the animal growth and development.

Dry matter and CP intakes (680 and $170 \mathrm{~g} / \mathrm{d}$, respectively) were close to those recommended (690 and $180 \mathrm{~g} / \mathrm{d}$, respectively) by the NRC (2001) for calves from 40 to $50 \mathrm{~kg}$ BW and average daily gain of $600 \mathrm{~g}$.

The lack of significant effect for the DM intake was also observed by Sandi \& Mühlbach (2001), however, Heinrichs 
et al. (2003) observed an increase in the total DM intake when prebiotics was added to the liquid diet of calves.

The mean DM intake during the first four weeks was $1.57 \% \mathrm{BW}$, which gives support to the strategy using as a weaning criterion the DM intake of calves in each BW.

No effect $(\mathrm{P}>0.05)$ of milk with or without acidifier on average daily gain (ADG) (450, 585 and $525 \mathrm{~g} / \mathrm{d})$ and feed efficiency $(0.45,0.58$ and 0.52$)$ were observed for age groups of calves from 0 to 4,5 to 8 and from 0 to 8 wks, respectively. These values were higher than those reported by Jaster et al. (1990) of $250 \mathrm{~g} / \mathrm{d}$ for calves continuously fed acidifier from birth up to 28 days of age. Zanetti et al. (1999), using as a acidifier, a product containing Lactobacillus, enzymes (amylase, protease and cellulases) and mannose, also reported no difference in ADG (310 and 380g/d) between calves fed or not with the acidifier.

However, Quigley et al. (1997) obtained greater ADG using galactosil-lactose in milk replacer. Dissimilar results were obtained by Sandi \& Mühlbach (2001), who used mannan oligosaccharide-based additive and concluded that calves fed the additive gained more weight ( $430 \mathrm{~g} / \mathrm{d})$ than those in the control treatment $(370 \mathrm{~g} / \mathrm{d})$, at the age of 56 days. Lima et al. (2006) tested the effect of probiotics to reduce the effects of heat stress on calves in the semi-arid northeastern of Brazil and reported average daily gain of $360 \mathrm{~g} / \mathrm{d}$. Zanetti et al. (1999) using acidifier containing Lactobacilus, enzymes and mannose observed better feed efficiency in animals that was fed the acidifier (0.82) as compared with the control group (0.60). Sandi \& Mühlbach (2001) observed feed efficiency of 0.80 and 0.99 for calves fed probiotic and weaned at 28 and 56 days of age.

It was observed effect $(\mathrm{P}<0.05)$ for fecal $\mathrm{pH}$ in the fourth wk only, where the animals that was fed the acidifier had higher $\mathrm{pH}$ (Table 3). For the others wk, the fecal $\mathrm{pH}$ ranged from 6.4 to 7.4 .

Table 3 - Fecal pH of calves fed milk with or without acidifier at different ages

\begin{tabular}{lcccc}
\hline $\begin{array}{l}\text { Calf age } \\
\text { (wk) }\end{array}$ & \multicolumn{3}{c}{ Milk } & P value \\
\cline { 2 - 3 } & $\begin{array}{c}\text { With } \\
\text { acidifier }\end{array}$ & $\begin{array}{c}\text { Without } \\
\text { acidifier }\end{array}$ & & \\
\hline 1 & 6.41 & 6.51 & 0.6131 & 11.86 \\
2 & 7.14 & 6.98 & 0.3037 & 8.32 \\
3 & 7.02 & 7.26 & 0.0715 & 7.39 \\
4 & 7.45 & 7.14 & 0.0089 & 6.12 \\
5 & 7.34 & 7.48 & 0.3265 & 5.64 \\
6 & 7.30 & 7.30 & 0.9685 & 5.42 \\
7 & 7.21 & 7.17 & 0.7388 & 6.41 \\
8 & 7.04 & 7.10 & 0.7334 & 8.93 \\
\hline${ }_{1} \mathrm{P}<0.05$. & & & &
\end{tabular}

It is suggested that the feed acidification has the potential to control the appearance of pathogenic bacteria, eliminating undesirable microorganisms that compete for nutrients and cause digestive problems such as diarrhea, enhancing growth and feed efficiency (Lucci, 1989). The mechanism through which organic acids act on behalf of the animal is due to the alteration of intestinal pH. However, this mechanism or advantage may not be effective because, according to Jaster et al. (1990), organic acids with $\mathrm{pH}$ value of 5.0 or higher would probably not have bactericidal or bacteriostatic effects. Moreover, they also reported that calves fed organic acids reduce the production of hydrochloric acid through the gastric juice to compensate the high feed acidity.

According to Jaster et al. (1990) and Merchen (1993), animals react to the intestinal acidity producing greater amounts of bile and pancreatic juice to make the intestinal $\mathrm{pH}$ stable and to provide appropriate environment for the action of digestive and absorptive enzymes. Therefore, it should be expected that the fecal $\mathrm{pH}$ is not influenced by the addition of acidifier.

There was no effect $(\mathrm{P}>0.05)$ for the number of eggs/g feces, and the means were $0.13,2.73,2.66,28.62,18.70,47.60$; 30.32 and 18.66 for the first to eighth wk, respectively. It could be observed that the number of eggs/g of feces increased from the fourth wk of age of the calves. However, it should be considered that the mean number observed was low. The reasons for the lack of effect, either or not in function of the acidifier fed, probably arise from the good health management practices adopted and the possibility that some larvae should have ecloded in the gastrointestinal tract of animals and was not detected because the technique employed was intended only for search for eggs.

The addition or not of the acidifier to the milk did not affect $(\mathrm{P}>0.05)$ the fecal scores and the runny nose of calves. The average number of days with fecal score of diarrhea was 6.5 and runny nose of 2.5, in a total of 56 days of experiment period.

The reports of literature pointed out situations that differ from those observed in this study, either in the occurrence (Zanetti et. Al, 1999; Abu Tarboush et al., 1996), either in the reduction (Quigley et al., 1997; Henrichs et al., 2003; Timmerman et al., 2005) of diarrhea in calves that were fed acidifiers.

The days, in which the calves' remains with fecal score of diarrhea, was important because they reflect the health control degree adopted in the calf rearing system. According to Timmerman et al. (2005), the greater was the number of days with fecal scores of diarrhea, the lower was the ability 
of the calf's immune response to external agents that cause health disorders, which represents higher morbidity and mortality rates and increase the cost with medicines and technical assistance fees.

For both, runny nose and fecal score, the original data was obtained in an indirect way, that is, from visual observation, which requires proper training of the person responsible for the collection of this data. This was because, especially for runny nose, the mere presence of runny nose does not necessarily mean disorder of the respiratory system, but it could be a natural elimination of secretions. Regarding the fecal score, Abe et al. (1999) reported that diarrhea was just one of several causes of more fluid fecal score, and the other causes were resulting from the diet composition, plasma osmolarity, intestinal motility and the absorption inefficiency.

In the second experiment, there was effect $(\mathrm{P}<0.05)$ of post-weaning concentrate with or without acidifier on the DM, OM, CP, EE, NDF and TC intakes ( $\mathrm{kg} / \mathrm{d}$ ), during the period from $13^{\text {th }}$ to $16^{\text {th }}$ wk of age. In other studied periods, regardless of the expression form $(\mathrm{kg} / \mathrm{d}$, \% BW), no differences were observed (Table 4).

The lowest intake observed in the four wk post-weaning reflected the change of diet supplied to the animals, because calves had no access to hay during the weaning period.

After weaning, the calves began to be fed only solid diet consisting of hay and post-weaning concentrate, which requires a period for the rumen microbiota to adapt to this type of feed, especially for the forage source, rich in vegetal cell wall, as well as an physiological adaptation, because there were changes in the digestion site, in the digestive events and in the form that the feed was used and absorbed (Lyford, 1993). However, this lower intake observed in the initial weeks following the post-weaning period did not seem to have reflected in the total intake over the following two months.

Dry matter and CP intakes (1740 and $217 \mathrm{~g} / \mathrm{d}$, respectively) were higher than those recommended (1,380 and $204 \mathrm{~g} / \mathrm{d}$, respectively) by the NRC (2001) for calves reared with milk or milk replacer, with $90 \mathrm{~kg}$ of BW and average daily gain of $600 \mathrm{~g}$.

The mean NDF intake showed considerable increase, which indicates the adaptation of animals to the forage intake. However, in absolute value and throughout the experimental period, regardless of the diet, the value was $1.3 \%$ of BW (Table 4), which seems high, what may have reduced intake as a result of the rumen filling effect.

No effects were observed $(\mathrm{P}>0.04)$ for calves fed postweaning concentrate with or without acidifier on ADG $(0.585,0.568$ and $0.576 \mathrm{~kg} / \mathrm{d})$ and feed efficiency $(0.24,0.10$, 0.07 ) from 9 to 12,13 to 16 and 9 to $16 \mathrm{wk}$, respectively. The lack of significant effect shows that the use of acidifier as prebiotic for these age groups did not represent additional benefits in ADG and feed efficiency for the use of nutrients, in this experimental condition. In general, for these age groups, it was recommended the use of probiotic based on

Table 4 - Nutrient intakes (kg/d and \% BW) of calves fed post-weaning concentrate with or without acidifier at different age groups

\begin{tabular}{|c|c|c|c|c|c|c|c|}
\hline \multirow[t]{3}{*}{ Nutrient intake } & \multirow[t]{3}{*}{ Calf age group(wk) } & \multicolumn{4}{|c|}{ Post-weaning concentrate } & \multirow{2}{*}{\multicolumn{2}{|c|}{ CV (\%) }} \\
\hline & & \multicolumn{2}{|c|}{ With acidifier } & \multicolumn{2}{|c|}{ Without acidifier } & & \\
\hline & & $\mathrm{kg} / \mathrm{d}$ & $\% B W$ & $\mathrm{~kg} / \mathrm{d}$ & $\% B W$ & $\mathrm{~kg} / \mathrm{d}$ & $\% \mathrm{BW}$ \\
\hline \multirow[t]{3}{*}{ Dry matter } & 9 to 12 & 0.8003 & 1.08 & 0.8074 & 1.08 & 16.32 & 18.30 \\
\hline & 13 to 16 & 2.6727 & 2.95 & 2.6916 & 2.94 & 1.10 & 5.83 \\
\hline & 9 to 6 & 1.7365 & 1.92 & 1.7495 & 1.91 & 3.84 & 7.11 \\
\hline \multirow[t]{3}{*}{ Organic matter } & 9 to 12 & 0.7142 & 0.96 & 0.7205 & 0.96 & 16.32 & 18.30 \\
\hline & 13 to 16 & 2.3851 & 2.63 & 2.4020 & 2.63 & 1.10 & 5.83 \\
\hline & 9 to 6 & 1.5497 & 1.71 & 1.5613 & 1.71 & 3.84 & 7.11 \\
\hline \multirow[t]{3}{*}{ Crude protein } & 9 to 12 & 0.0998 & 0.14 & 0.1007 & 0.13 & 16.32 & 18.30 \\
\hline & 13 to 16 & 0.3333 & 0.37 & 0.3356 & 0.37 & 1.10 & 5.83 \\
\hline & 9 to 16 & 0.2165 & 0.24 & 0.2182 & 0.24 & 3.83 & 7.11 \\
\hline \multirow[t]{3}{*}{ Ether extract } & 9 to 12 & 0.0146 & 0.02 & 0.0147 & 0.02 & 16.29 & 18.28 \\
\hline & 13 to 16 & 0.0486 & 0.05 & 0.0490 & 0.05 & 1.10 & 5.84 \\
\hline & 9 to 16 & 0.0316 & 0.04 & 0.0318 & 0.04 & 3.85 & 7.12 \\
\hline \multirow[t]{3}{*}{ Neutral detergent fiber } & 9 to 12 & 0.5740 & 0.77 & 0.5790 & 0.77 & 16.32 & 18.30 \\
\hline & 13 to 16 & 1.9169 & 2.12 & 1.9305 & 2.11 & 1.10 & 5.83 \\
\hline & 9 to 16 & 1.2454 & 1.38 & 1.2548 & 1.37 & 3.84 & 7.11 \\
\hline \multirow[t]{3}{*}{ Total carbohydrates } & 9 to 12 & 0.6137 & 0.83 & 0.6191 & 0.83 & 16.32 & 18.30 \\
\hline & 13 to 16 & 2.0495 & 2.26 & 2.0640 & 2.26 & 1.10 & 5.83 \\
\hline & 9 to 16 & 1.3316 & 1.47 & 1.3415 & 1.47 & 3.84 & 7.11 \\
\hline
\end{tabular}


microorganism strains to improve intake, use of nutrients (especially fibrous) and average daily gain, as reported by Arenas et al. (2007). The lack of significant effect on the DM intake, ADG and feed efficiency was also observed by Güler et al. (2006).

The fecal $\mathrm{pH}$ was not affected $(\mathrm{P}>0.05)$ by post-weaning concentrate with or without acidifier; however, regardless of the that, as the age of calves advanced, fecal pH tended to reduce, which average value at the beginning of the experiment was 6.73 ( $9 \mathrm{wk}$ ) and at the end was 5.36 (16 wk). The lowest $\mathrm{pH}$ observed at the end of the experimental period may be resulting from the microbial activity in the large intestine, because substrates from the upper compartments of the digestive tract produce considerable amounts of acids, which are eliminated in the feces with the reduction in the fecal $\mathrm{pH}$.

The offer of post-weaning concentrate with acidifier did not reduced $(\mathrm{P}>0.05)$ the number of eggs of helminthes/g of feces, with average values of 27.79, 22.51, 56.45, 55.95, $98.30,112.42$, 84.06 and 115.48 for the 9 throughout 19 wk, respectively. Although, despite the effect observed, the presence of helminthes increased from the $13 \mathrm{wk}$ of age of the calves. However, the average number observed may be considered low. The lack of effect may be due to the same reasons as those described for the first experiment.

There was no effect $(\mathrm{P}>0.05)$ on the fecal scores and runny nose for the continuously addition of acidifier to post-weaning concentrate for calves from weaning until the fourth month of age, with averages of 3.5 and 2.5 days, respectively, for a total of 56 days. The lack of

Table 5 - Dry matter and crude protein (kg/d and \% BW) intakes of calves fed milk replacer with or without acidifier at different age groups

\begin{tabular}{|c|c|c|c|c|}
\hline \multirow{2}{*}{$\begin{array}{l}\text { Nutrient } \\
\text { intake }\end{array}$} & \multirow{2}{*}{$\begin{array}{c}\text { Calf age } \\
\text { group (wk) }\end{array}$} & \multicolumn{2}{|c|}{ Milk replacer } & \multirow[t]{2}{*}{ CV (\%) } \\
\hline & & $\begin{array}{c}\text { With } \\
\text { acidifier }\end{array}$ & $\begin{array}{l}\text { Without } \\
\text { acidifier }\end{array}$ & \\
\hline & \multicolumn{4}{|c|}{ kg/day } \\
\hline \multirow[t]{3}{*}{ Dry matter } & 0 to 4 & 0.7816 & 0.7602 & 19.70 \\
\hline & 5 to 8 & 1.6170 & 1.5354 & 22.36 \\
\hline & 0 to 8 & 1.9993 & 1.1478 & 20.70 \\
\hline \multirow[t]{4}{*}{ Crude protein } & 0 to 4 & 0.0637 & 0.0599 & 44.13 \\
\hline & 5 to 8 & 0.2114 & 0.1967 & 31.09 \\
\hline & 0 to 8 & 0.1376 & 0.1283 & 32.80 \\
\hline & \multicolumn{4}{|c|}{$\% \mathrm{BW}$} \\
\hline \multirow[t]{3}{*}{ Dry matter } & 0 to 4 & 1.37 & 1.41 & 18.24 \\
\hline & 5 to 8 & 2.06 & 1.96 & 17.69 \\
\hline & 0 to 8 & 1.53 & 1.46 & 15.39 \\
\hline \multirow[t]{3}{*}{ Crude protein } & 0 to 4 & 0.11 & 0.11 & 41.64 \\
\hline & 5 to 8 & 0.27 & 0.25 & 25.57 \\
\hline & 0 to 8 & 0.17 & 0.16 & 26.25 \\
\hline
\end{tabular}

effect observed, possibly, reflects the good nutritional and health status of calves in function of the health program employed.

In the third experiment, no effect was observed $(\mathrm{P}>0.05)$ for milk replacer with or without acidifier for DM and CP intakes $(\mathrm{kg} / \mathrm{d}, \% \mathrm{BW})$ at different age groups of calves (Table 5).

The lack of significant effect on the DM intake was also observed by Sandi \& Mühlbach (2001) and Güler et al. (2006), while Meyer et al. (2001) and Heinrichs et al. (2003) reported increase in the total DM intake with the addition of prebiotic to the liquid diet of calves.

Dry matter and CP intakes (770 and $130 \mathrm{~g} / \mathrm{d}$, respectively) was higher and lower than those recommended (690 and $180 \mathrm{~g} / \mathrm{d}$, respectively), by the NRC (2001) for calves from 40 to $50 \mathrm{~kg} \mathrm{BW}$ and average daily gain of $600 \mathrm{~g} / \mathrm{d}$. However, was similar to the DM intake ( $780 \mathrm{~g} / \mathrm{d})$ described by Jaster et al. (1990).

Dry matter was of $770 \mathrm{~g} / \mathrm{d}$, regardless the addition or not of acidifier to the milk replacer during the firsts four weeks, being basically a result from the intake observed over the last two weeks, where the calves had average age from 28 to 30 days.

Although Greenwood et al. (1997) have suggested a DM intake of $1.5 \%$ of BW as a weaning criterion, total DM intake during the first four wks, regardless of the use of milk replacer with or without acidifier, was $1.39 \%$ BW, which did not support the strategy of using DM intake based on BW as a weaning criterion (Table 6). However, Nussio et al. (2003) testing three weaning criterion (postweaning concentrate intake equal to $700 \mathrm{~g} / \mathrm{d}$, for three consecutive days; post-weaning concentrate intake equivalent to $1.5 \%$ of $\mathrm{BW}$, for three consecutive days, and at the age of eight wk), considered that any weaning criterion above could be used, whereas the decision depends on the handling easiness of each property.

Table 6 - Fecal pH of calves fed milk replacer with or without acidifier at different ages

\begin{tabular}{lcccc}
\hline $\begin{array}{l}\text { Age of } \\
\text { calf }(w k)\end{array}$ & \multicolumn{2}{c}{ Milk replacer } & P value & CV (\%) \\
\cline { 2 - 3 } & $\begin{array}{c}\text { With } \\
\text { acidifier }\end{array}$ & $\begin{array}{c}\text { Without } \\
\text { acidifier }\end{array}$ & & \\
\hline 1 & 6.27 & 6.42 & 0.4421 & 4.82 \\
2 & 6.88 & 6.95 & 0.7911 & 6.68 \\
3 & 6.87 & 7.10 & 0.2891 & 5.19 \\
4 & 6.87 & 7.14 & 0.2590 & 5.83 \\
5 & 7.03 & 7.43 & 0.0284 & 3.87 \\
6 & 6.84 & 7.29 & 0.0168 & 3.97 \\
7 & 6.85 & 7.32 & 0.1480 & 7.36 \\
8 & 6.95 & 6.86 & 0.8158 & 8.80 \\
\hline $1 \mathrm{P}<0.05$. & \multicolumn{3}{c}{}
\end{tabular}


No effect $(\mathrm{P}>0.05)$ was observed for the ADG and feed efficiency when calves was fed milk replacer with or without acidifier. The average daily gain, regardless of the diet was 585, 568 and $576 \mathrm{~g} / \mathrm{d}$, respectively, for the average and weighted daily gains. These values were higher than those reported (250g/day) by Jaster et al. (1990) for calves fed acidifier on a continuously basis between birth to 28 days of age. Zanetti et al. (1999) also reported no difference in the ADG (310 and $380 \mathrm{~g} / \mathrm{d}$, respectively) for calves fed milk replacer with or without acidifier. The feed efficiency was not $(\mathrm{P}>0.05)$ affected by the addition of acidifier to milk replacer, with means of $0.80,0.55$ and 0.69 for age groups from 0 to 4,5 to 8 and 0 to 8 wks, respectively. However, Zanetti et al. (1999) observed better feed conversion for the calves that was fed milk replacer with acidifier (1.22) compared with the control group (1.66).

There was no effect $(\mathrm{P}>0.05)$ for fecal $\mathrm{pH}$ for calves fed milk replacer with or without acidifier, except at the fifth and sixth wk, whereas the calves that were fed milk replacer with acidifier showed lower fecal pH (Table 6). The fecal $\mathrm{pH}$ tended to become alkaline for calves that did not receive the acidifier. Probably, this observation comes from the $\mathrm{pH}$ neutralization in the content that formed the fecal mass by the ruminal and intestinal buffering agents required for digestive processes that occur in these compartments. Donovan et al. (2002) also reported no effect on the fecal $\mathrm{pH}$ of calves fed diets with antibiotics or probiotics.

As in the first and second experiments, no effect was observed $(\mathrm{P}>0.05)$ on the fecal scores and occurrence of runny nose of calves from birth up to two months of age according to the continuously addition of acidifier to milk replacer. The number of days that the animals remained with fecal score of diarrhea was 6 days and runny nose of 7.5 days in a total of 56 days. In this item, the same considerations described in first experiment for the lack of effect were valid, as the same practices adopted in that experimental condition were also applied to calves in this experiment.

Although the inclusion of the occurrence of diarrhea to the mathematical model used in the statistical analysis did not influence the performance variables to the point where significant differences could be observed, its inclusion as co-variable seems to be justifiable when the diarrhea occurrence level was high, because it can contribute considerably for the explanation of the results. Therefore, other experiments of this nature should be conducted to validate its application in calves.

As observed, contradictory results in studies with prebiotics were frequent and justifiable. Possible reasons for this inconsistency of results were, among others: the diversity in the composition and quality prebiotic products, dose administered, and the management condition imposed to the animals, with higher or lower stress level.

The possibility of observing positive response in the use of prebiotics for calves from dairy herds depends on several factors including the management level and the stress level that these animals are submitted to. It is reasonable to assume that the best results obtained with the use of prebiotics occurred under stress conditions, namely at farms where there were still gaps in the management, which did not occur in the research conducted here.

As the use of prebiotics was related to lower dependence on the use of antibiotics, it is expected that the industry could provide more effective products in order to improve the animal performance with no residues that could be harmful to human health.

\section{Conclusions}

In the dosages used, the addition of acidifier to milk, replacer or post-weaning concentrate does not improve the performance and health status of calves from birth to 4 months old.

\section{Literature Cited}

ABE, A.; MIYAJIMA, Y.; HARA, T. et al. Factors affecting water balance and fecal moisture content in suckling calves given dry feed. Journal of Dairy Science, v.82, p.1960-1967, 1999.

ABU TARBOUSH, H.M.; AL SAIADY, M.Y.; KEIR EL DIN, A.H. Evaluation of diet containing lactobacilli on performance, fecal coliform, and lactobacilli of young dairy of calves. Animal Feed Science and Technology, v.57, n.1-2, p.39-49, 1996.

ARENAS, S.E.; REIS, L.S.L.S.; FRAZATTI-GALLINA, N.M. et al. Efeito do probiótico proenzime ${ }^{\circledR}$ no ganho de peso em bovinos. Archivos de Zootecnia, v.56, n.213, p.75-78, 2007.

DONOVAN, D.C.; FRANKLIN, S.T.; CHASE, C.C.L. et al. Growth and health of Holstein calves fed milk replacers supplemented with antibiotics or enteroguard. Journal of Dairy Science, v.85, p.947-950, 2002.

GOMES, F.P. Curso de estatística experimental. 2.ed. Piracicaba: Escola Superior de Agricultura Luiz de Queiroz, 1963. 384p.

GREENWOOD, R.H.; MORRILL, J.L.; TITGEMEYER, E.C. Using dry feed intake as a percentage of initial body weight as a weaning criterion. Journal of Dairy Science, v80, n.10, p.2542-2546, 1997.

GÜLER, O.; YANAR, M.; BAYRAM, B. et al. Performance and health of dairy calves fed limited amounts of acidified milk replacer. South African Journal of Animal Science, v.36, n.3, p.149-154, 2006.

HEINRICHS, A.J.; JONES, C.M.; HEINRICHS, B.S. Effects of mannan oligosaccharide or antibiotics in neonatal diets on health and growth of dairy calves. Journal of Dairy Science, v.86, p.4064-4069, 2003. 
JASTER, E.H.; McCOY, G.C.; TOMKINS, T. et al. Feeding acidified or sweet milk replacer to dairy calves. Journal of Dairy Science, v.73, n.12, p.3563-3566, 1990.

LIMA, J.M.M; GUIDONI, A.L. Importância da variável ocorrência de diarréia em modelos matemáticos para análise de experimentos de leitões. In: REUNIÃO ANUAL DA SOCIEDADE BRASILEIRA DE ZOOTECNIA, 31., 1994, Maringá. Anais... Maringá: Sociedade Brasileira de Zootecnia, 1994. p.31.

LIMA, P.O.; MOURA, A.A.; FAÇANHA, D.A. et al. Desempenho e indicadores de estresse térmico em bezerras alimentadas com sucedâneo lácteo com ou sem probiótico no semi-árido brasileiro. Archivos Latinoamericanos de Produccion Animal, v.14, n.2, p.49-55, 2006.

LUCCI, C. Bovinos leiteiros jovens: nutrição, manejo e doenças. São Paulo: Nobel - EDUSP, 1989. 371p.

LYFORD, S. Crecimiento y desarrollo del aparato digestivo de los rumiantes. In: CHURCH, D.C. (Ed.) El rumiante: fisiología digestiva y nutrición. Zaragoza: Acríbia, 1993. p.47-68.

MAGALHÃES, M.N.; LIMA, A.C.P. Noções de probabilidade e estatística. 3.ed. São Paulo: IME-USP, 2001. 392p.

MARQUES, D.C. Criação de bovinos. 7.ed. Belo Horizonte: CVP Consultoria Veterinária e Publicações, 2003. 586p.

MERCHEN, N.R. Digestión, absorción y excreción en los rumiantes. In: CHURCH, D.C. (Ed.) El ruminante: fisiología digestiva y nutrición. Zaragoza: Acríbia, 1996. p.191-223.

MEYER, P.M.; PIRES, A.V.; BAGALDO, A.R. et al. Adição de probiótico ao leite integral ou sucedâneo e desempenho de bezerros da raça holandesa. Scientia Agrícola, v.58, n.2, p.215-221, 2001.

NATIONAL RESEARCH COUNCIL - NRC. Nutrient requirements of dairy cattle. 7.ed. Washington, D.C.: National Academic Press, 2001. 362p.

NUSSIO, C.M.B.; RODRIGUES, A.A.; SANTOS, F.A.P. et al. Avaliação de critérios para desaleitamento de bezerras leiteiras. In: REUNIÃO ANUAL DA SOCIEDADE BRASILEIRA DE ZOOTECNIA, 40., 2003, Santa Maria. Anais... Santa Maria: Sociedade Brasileira de Zootecnia, 2003.
PALENZUELA, P.R. Los ácidos orgánicos como agentes antimicrobianos. In: REBOLLAR, A.P.G.; BLAS, C.; MATEOS, G.G. (Eds.) Curso de Especialización FEDNA: avances en nutrición y alimentación animal. Madrid: 2003.

QUIGLEY, J.D.; DREWRY, J.J.; MURRAY, L.M. et al. Body weight gain, feed efficiency, and fecal scores of dairy calves in response to galactosyl-lactose or antibiotics in milk replacers. Journal of Dairy Science, v.80, n.8, p.17511754, 1997.

SALMOND, C.V.; KROL, R.G.; BOOTH J.R. The effect of food preservatives on $\mathrm{pH}$ homeostasis in Escherichia coli. Journal of General Microbiology, v.130, p.2845-50, 1984.

SANDI, D.; MUHLBACH, P.R.F. Desempenho de bezerros da raça Holandesa com desaleitamento aos 28 ou 56 dias de idade, com ou sem aditivo à base de oligossacarídeo de manana. Ciência Rural, v.31, n.3, p.487-490, 2001.

STATISTICAL ANALYSIS SISTEMS - SAS. Statistical analysis system user's guide: basics. 7.ed. Cary: SAS Institute, 2000. (CD-ROM).

SHEATER, A.L. Detection of worm eggs in the faeces of animals and some experiences in the treatment of parasitic gastritis in cattle. Journal of Comparative Pathology and Theriogenology, v.36, p.71-90, 1923.

SNEDECOR, G.W.; COCHRAN, W.G. Statistical methods. 8.ed Iowa: Iowa University Press, 1989. 503p.

TIMMERMAN, H.M.; MULDER, L.; EVERTS, H. et al. Health and growth of veal calves fed milk replacers with or without probiotics. Journal of Dairy Science, v.88, p.2154-2165, 2005.

ZANETTI, M.A.; SCHALCH, E. ; ROSSINI, A.J. et al. Uso de aditivos em dietas de bezerros holandeses. In: REUNIÃO ANUAL DA SOCIEDADE BRASILEIRA DE ZOOTECNIA, 36., 1999, Porto Alegre. Anais... Porto Alegre: Sociedade Brasileira de Zootecnia, 1999. CD-ROM.

YOUNG, K.M.; FOEGEDING, P.M. Acetic, lactic and citric acids and $\mathrm{pH}$ inhibition of Listteria Monocytogenes: the effect on intracellular pH. Journal of Applied Bacteriology, v.74, p.515-20, 1993. 